\title{
Microwear Behavior Study of Carburization and Ion Plasma Nitriding of P20 Steel
}

\author{
H. S. M. Lopes ${ }^{1}$, J. O. Pereira Neto ${ }^{1}$, J. A. Moreto ${ }^{2}$, M. D. Manfrinato ${ }^{1}$, N. C. Cruz ${ }^{3}$, L. S. \\ Rossino ${ }^{1,4}$ \\ ${ }^{1}$ Sorocaba Technological College (FATEC), Sorocaba/SP - Brazil \\ ${ }^{2}$ Federal Institute Goiano (IF Goiano), Morrinhos/GO - Brazil \\ ${ }^{3}$ Paulista State University (UNESP), Sorocaba/SP - Brazil \\ ${ }^{4}$ Federal University of São Carlos (UFSCar), Sorocaba/SP - Brazil
}

\begin{abstract}
The P20 steel, mainly used in plastic molds, was thermochemical treated by ion plasma nitriding, solid and gas carburization. In this work, the solid and gas carburization were carried out at $925^{\circ} \mathrm{C}$ in four different times. The ion plasma nitriding was performed at $520^{\circ} \mathrm{C}$ in three different times. It was observed that the thermochemical treatment increases the microwear resistance of the studied material. The gas carburizing treatment produced a bigger surface microhardness. Longer times of treatment increase effectiveness of thickness layer in all cases. The solid carburization produced larger thickness layer than gas carburization and ion nitriding.
\end{abstract}

Keywords: Gas carburizing, solid carburizing, ion plasma nitriding, P20, microwear.

\section{Introduction}

The development of plastic industry assumed a prominent position in the world industry production [1]. The mold steels require some properties to fit the process of plastic injection. They need to present good impact, microwear and mechanical resistance and high machinability [2]. For this, the most common and used methods, currently, for mold steels, are thermochemical treatments as nitriding and carburizing process [3]. P20 is a steel commonly used in the manufacturing of polymer injection molds. P20 is provided by manufactures in the quenched and tempered condition [4].

The aim of this work was to realize the ion plasma nitriding, gas and solid carburizing treatments on the P20 steel. The differents values of microhardness and microwear will be compared for each thermochemical treatment.

\section{Experimental}

The material used in this investigation was AISI P20 steel, the main steel used on plastic injection molds. The studied material was achieved quenched and tempered, with 34HRC of hardness. Table 1 lists the chemical composition of their major elements. Optical Emission Spectroscopy using a Spectrometer Ametek Spectromaxx, model LMF05, situated at the Sorocaba Technological College, determined the chemical composition.

Table 1 - Chemical Composition (wt\%) of the AISI P20 (W. Nr. 12.311) steel, according to W Nr. standard [5]

\begin{tabular}{cccccc}
\hline Elements & $\mathrm{C}$ & $\mathrm{Mn}$ & $\mathrm{Si}$ & $\mathrm{Cr}$ & $\mathrm{Mo}$ \\
\hline Nominal & $0.35-0.45$ & $1.30-1.60$ & $0.20-0.40$ & $1.80-2.10$ & $0.15-0.25$ \\
\hline Obtained & 0.434 & 1.49 & 0.306 & 1.81 & 0.190 \\
\hline
\end{tabular}

Presenting and corresponding author: H.S. M. Lopes, henrique_sml@hotmail.com 
The solid carburizing treatment was carried out at the Heat Treatment Laboratory of Sorocaba Technological College. For this a mixture of $80 \%$ charcoal and $20 \%$ calcium carbonate $(\mathrm{CaCO} 3)$ was used. A box was used to store the specimen with the carburizing mixture, which was properly fenced to not occur leaking of carburizing gas. After the sealing, it was left at room temperature for 24 hours to not crack the seal due to sudden temperature change when placed into furnace. The treatment was done at a fixed temperature of $925^{\circ} \mathrm{C}$ varying the time of $2,4,6$ and 8 hours.

The gas carburizing treatment was performed at the Thermix Metal Heat Treatment Ltda (Sorocaba/Brazil). It consists in obtain carbon monoxide from gases strongly carburizing (methane, propane or ethane). The treatment was performed at a fixed temperature of $925^{\circ} \mathrm{C}$, varying the time of $1,2,3$ and 4 hours. The carbon potential in the furnace was of $1.3 \%$, the propane and methane flow was 1000 and $60 \mathrm{~cm}^{3} / \mathrm{h}$, respectively, and the pressure $6 \mathrm{psi}$. All carburized specimens were quenched at $860^{\circ} \mathrm{C}$ for 30 minutes and tempered at $180^{\circ} \mathrm{C}$ for 20 minutes.

The ion plasma nitriding was performed at the Metal Plasma Metallurgical Cia (São José dos Campos/Brazil). Ion plasma nitriding is a thermochemical treatment process that diffuses nitrogen into the surface of a metal to create a case hardened surface. The nitrogen reacts with de iron and alloying elements, forming nitrides of high hardness and wear resistance. The treatment was carried out using a fixed temperature of $520^{\circ} \mathrm{C}$, varying the time in 2,4 and 6 hours. The atmosphere in the furnace was $75 \% \mathrm{~N}_{2}$ and $25 \% \mathrm{H}_{2}$ and the pressure $300 \mathrm{~Pa}$.

Surface microhardness profile tests were performed at the Metallography Laboratory of Sorocaba Technological College, using a Mitutoyo equipment, HM 220 model, load of $0.2 \mathrm{kgf}$ and load application time of 15 seconds. The case depth was determined according to the drop in the layer hardness, reaching the substratum hardness.

The microwear tests were carried out using a microwear equipment with bearing steel ball AISI 52100 with 25.4 mm of diameter, $744 \mathrm{rpm}$ of rotation, normal load of $8.3 \mathrm{~N}$ during 10 minutes. To determine the quantity of removed material, wear rate and the crater height, the equations (1), (2), (3) were used, considering $b \ll<R$.

For a spherical wear crater produced by a Sphere in a flat specimen, the wear volume $\mathrm{V}$ can be measured according to equation (1), where $\mathrm{R}$ is the ball radius and $\mathrm{b}$ is the average diameter of the wear crater. By this equation it is possible to note that higher is the wear volume less will be the wear resistance. Equation (2) shows the wear rate (K) which can be interpreted as the wear volume of material as function of distance $(\mathrm{S})$ and the load applied (N) [6]. This parameter measures the severity of wear.

$$
\begin{aligned}
& V=\pi \frac{b^{4}}{64 R^{2}}\left(R-\frac{b^{2}}{8 R}\right) \approx \frac{\pi b^{4}}{64 R} \\
& \mathrm{~K}=\frac{1}{\mathrm{~N} \cdot \mathrm{S}} \cdot \frac{\pi \cdot \mathrm{b}^{4}}{64 \cdot \mathrm{R}} \\
& h=\sqrt{\frac{V}{\pi \cdot R}}
\end{aligned}
$$

\section{Results and Discussion}

Figure 3.1 (a) presents the hardness profile of the specimen treated by solid carburizing. As can be seen the treatment increases the surface hardness, reaching $720 \mathrm{mHV}$ in 2 hours. In Fig. 3.1 (b) is shown the hardness profile of the specimen treated by gas carburizing. This method presented an increase on the surface hardness comparing to solid carburizing, reaching $923 \mathrm{mHV}$ in 2 hours.

The thickness of the effective layer formed on the solid carburizing process is higher when compared with the gas carburizing. In gas carburizing process a thickness of $0.8,1.1,1.4$ and 1.7 was found for 1, 2, 3 and 4 hours of treatment, respectively. For the solid carburizing, a thickness of $0.75,2: 57,2.73$ and 2.78 was determined for 2, 4, 6 and 8 hours of treatment, respectively.

Figure 3.1 (c) shows the hardness profile of specimen treated by ion plasma nitriding. The treatment promoted a surface hardness of $845 \mathrm{mHV}$ in two hours. However, the case depth was lower compared to the other treatments, reaching $0.2,0.25$ and $0.45 \mathrm{~mm}$ in 2, 4 and 6 hours. The nitriding treatment promotes a white layer that reduces friction, improves resistance to corrosion and fatigue $[2,7,8,9,10,11]$. The white layer reached $7.15 \mu \mathrm{m}$ on the 2 hours sample, $9.35 \mu \mathrm{m}$ on the 4 hours sample and $11.5 \mu \mathrm{m}$ on the 6 hours sample. 


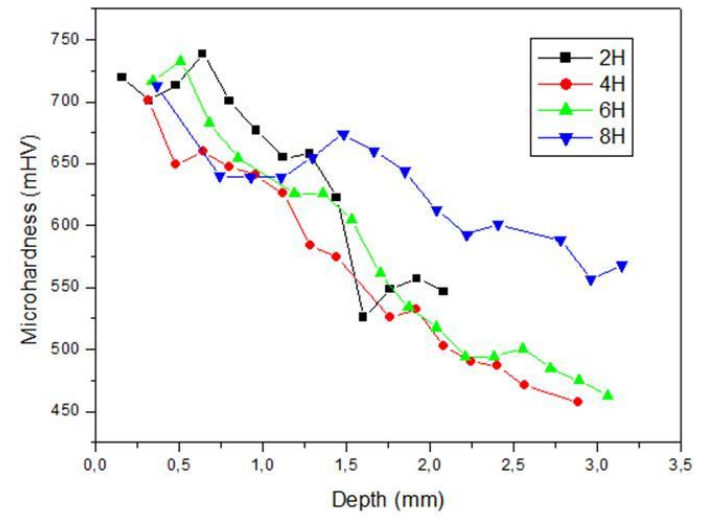

(a)

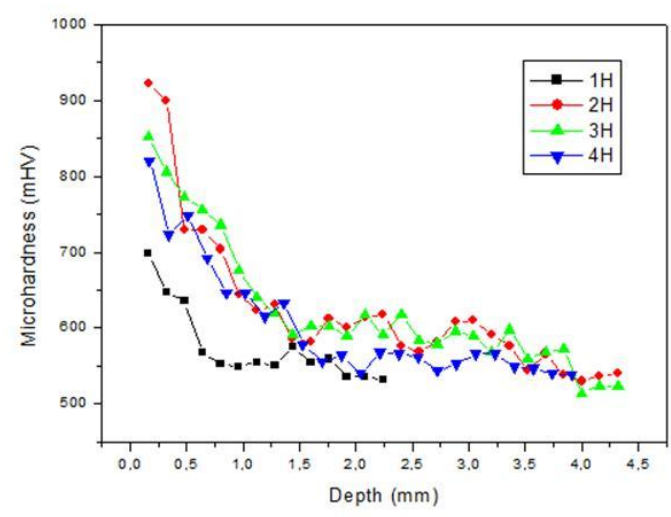

(b)

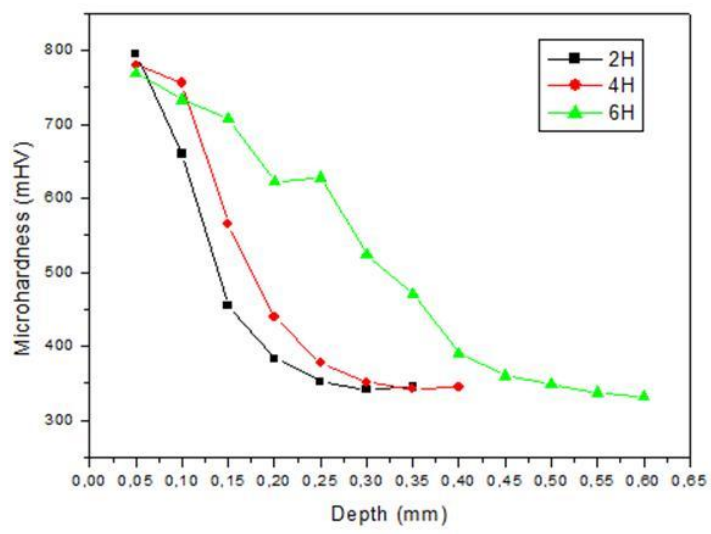

(c)

Figure 3.1 - Hardness profile of (a) solid carburization (b) gas carburization and (c) ion plasma nitriding

It is possible to note in Fig 3.2 that all thermochemical treatments realized dramatically increased the microwear resistance of the studied material, proving its efficiency. In general, the specimens treated by gas carburization obtained the most satisfactory microwear volume results due to its high surface hardness and the considerable thickness of the layer. In the case of gas carburizing and ion nitriding treatments, increasing the treatment time, there was an increase in the wear volume due to decrease in surface hardness. Consequently, it also increased the wear rate of this specimen.

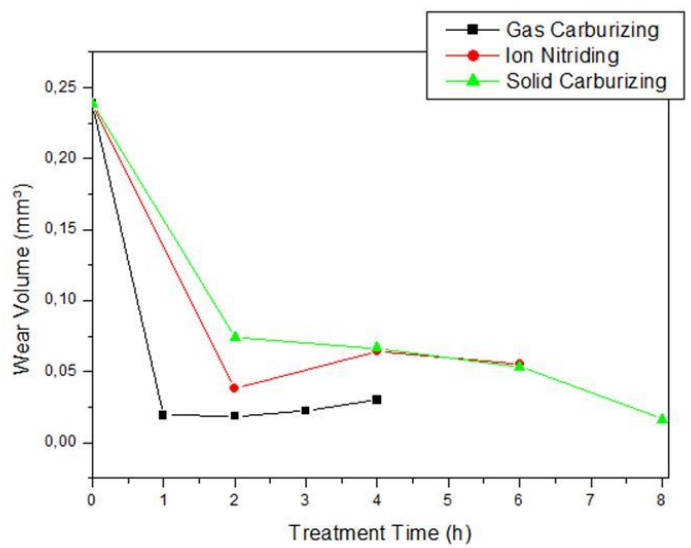

(a)

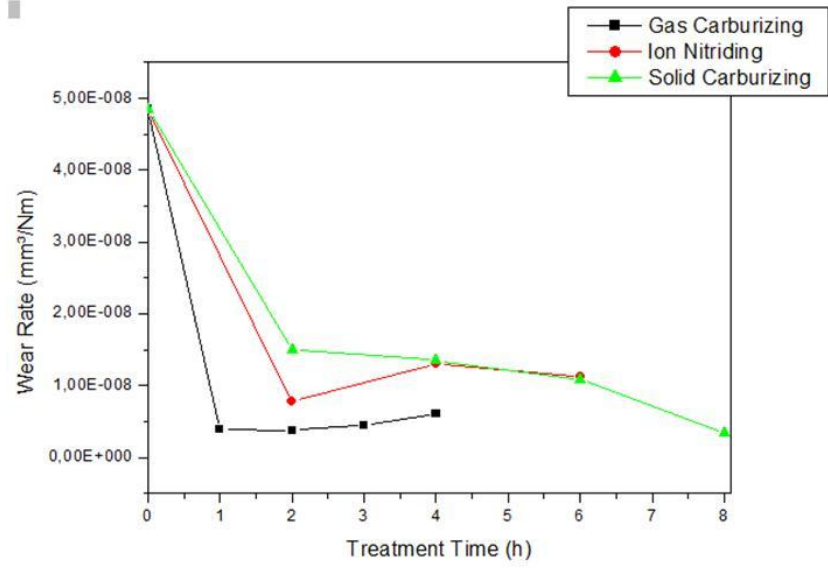

(b)

Figure 3.2 - Volume microwear (a) and wear rate (b) of the studied material with and without treatment.

The specimen treated via solid carburizing during $8 \mathrm{~h}$ showed the lowest wear rate and wear volume. However, in solid carburizing process, the behavior was the opposite when compared to others. The nitrided and gas carburizing specimens showed an increase in wear resistance with increasing of treatment time. For solid carburizing process, the wear volume declines with increasing of treatment time. This is because the hardness of the layer formed remains to depths greater than other thermal treatments. 
As can be seen, the specimen treated via gas carburizing has a very similar wear resistance of the specimen treated by carburizing solid during $8 \mathrm{~h}$.

Figure 3.2 (b) shows that the wear rate and the wear volume are similar. In other words, as higher the amount of wear higher will be the wear rate.

It can be observed in Table 3.1 that the crater height does not reached the substrate of any specimen.

Table 3.1 - Crater height compared to the layer depth.

\begin{tabular}{ccc}
\hline Thermochemical Treatment & Crater Height $(\mathrm{mm})$ & Layer Depth $(\mathrm{mm})$ \\
\hline Solid Carburizing 2 hours & 0.043 & 2.75 \\
\hline Solid Carburizing 4 hours & 0.040 & 2.73 \\
\hline Solid Carburizing 6 hours & 0.036 & 2.78 \\
\hline Solid Carburizing 8 hours & 0.020 & 0.80 \\
\hline Gas Carburizing 1 hour & 0.022 & 1.10 \\
\hline Gas Carburizing 2 hours & 0.022 & 1.40 \\
\hline Gas Carburizing 3 hours & 0.023 & 1.70 \\
\hline Gas Carburizing 4 hours & 0.027 & 0.20 \\
\hline Ion Nitriding 2 hours & 0.031 & 0.25 \\
\hline Ion nitriding 4 hours & 0.040 & 0.45 \\
\hline Ion Nitriding 6 hours & 0.037 & \\
\hline
\end{tabular}

\section{Conclusions}

The P20 steel without treatment showed lower hardness and therefore lower wear resistance compared with the material treated.

The gas carburizing treatment showed greater hardness compared to the other treatments. However, the solid carburizing treatment presented higher thickness of the effective layer.

The ion nitriding treatment showed high surface hardness with the presence of white layer formation which has important properties for plastic injection molds as lower friction, increased of the fatigue resistance and decreased of the corrosion process.

Thus it can be concluded that heat treatments were satisfactory, with great improvement in tribological properties of the material as surface hardness and wear resistance.

\section{Acknowledgements}

The authors would like to thank the Thermix Ltda by the gas carburizing treatment, the MetalPlasma Cia by the ion nitriding treatment, Federal University of São Carlos, Paulista State University and Sorocaba Technological College for providing the laboratories facilities.

\section{References}

1. L. Sors. Moldes e Matrizes, Hemus, São Paulo, 2002.

2. A. L. V. Costa e Silva, P. R. Mei. Aços e ligas especiais, 3 ed., Blucher, São Paulo, 2010.

3. ASM Metals Handbook. Properties and Selection Irons, Steels and High Performance Alloys, v. 1, 2005.

4. V. Chiaverini. Aços e Ferros Fundidos, 4 ed., ABM, São Paulo, 1977.

5. Favorit Special Steels. AISI P20. Available in: http://www.favorit.com.br/produtos/acos-ferramenta/aco-aisi-p20/. Access in 08/07/2014.

6. K. L. Rutherford, I. M. Hutchings. A micro-abrasive wear test with particular application to coated systems. Surface and Coatings Technology, 79 (1996) p 231-239.

7.M. Wolfart Jr. Nitretação a Plasma do Aço ABNT 316L em Baixas Temperaturas, Doutorado, Universidade Federal do Rio Grande do Sul, 2002.

8. R. F. Reis, W. H. Schreiner, P. C. Borges. Nitretação do Aço Inoxidável AISI 316L a Altas Temperaturas: Influência na Camada Nitretada, Revista Brasleira de Aplicações de Vácuo, 25-3 (2006) p. 183-187.

9. R. R. Caetano, A. R. Franco Jr., C. E. Pinedo. Características De Formação Da Austenita Expandida Na Nitretação Por Plasma Do Aço Inoxidável Austenítico AISI 316 Grau ASTM F138, In: CBECIMAT, Anais, 2002.

10. M. D. Manfrinato. Influência da Nitretação a Plasma no Comportamento em Fadiga dos Aços Inoxidáveis Austeníticos AISI 304 e 316 , Dissertação, Escola de Engenharia de São Carlos USP, 2006.

11. C. E. Pinedo. Nitretação Por Plasma para Endurecimento Superficial de Aços Ferramenta, MM, (2004) p.122-133. 